\title{
Intracranial dermoid cyst rupture with midbrain and thalamic infarction
}

\begin{tabular}{|c|c|}
\hline Figure & $\begin{array}{l}\text { Various brain MRI findings of dermoid cyst rupture with cerebral } \\
\text { infarctions }\end{array}$ \\
\hline
\end{tabular}
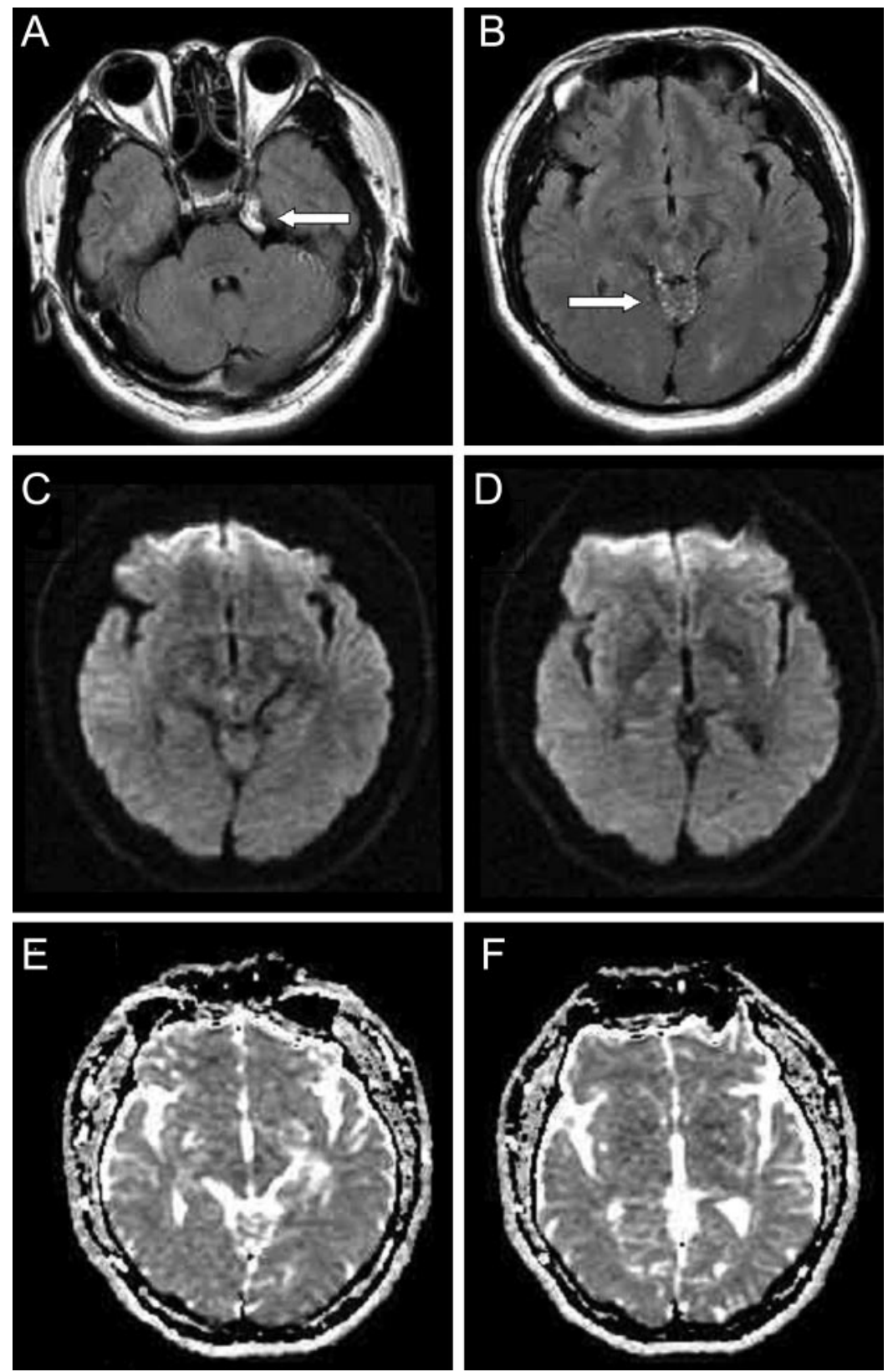

T1-weighted brain MRI shows cystic mass in the left cerebellopontine angle cistern ( $A$, arrow) and multiple tiny fatty droplets on quadrigeminal, ambient, interpeduncular, and suprasellar cistern (B, arrow). Diffusion-weighted image $(C, D)$ and apparent diffusion coefficient image $(E, F)$ show small acute infarction in right midbrain and right medial thalamus.
A 39-year-old man developed dizziness and diplopia. Examination showed medial gaze palsy of the right eye. He had no headache, vertical gaze palsy, or skew deviation. A CSF examination was not performed. MRI (figure) showed cystic mass and acute infarction. After 7 days heparization, the mass was removed by surgery and pathology confirmed the dermoid cyst. After operation, the neurologic abnormality disappeared. Epidermoid cyst, arachnoid cyst, and cystic craniopharyngioma are differential diagnoses. Although intracranial dermoid cysts are rare benign tumors, ${ }^{1}$ surgery is the only treatment and rupture of a cyst can lead to cerebral vasospasm or vasculitis. $^{2}$

Min Goo Kang, MD, Kyung Jib Kim, MD, Jung Im Seok, MD, Dong Kuck Lee, MD, PhD, Daegu, South Korea

\section{Disclosure: The authors report no disclosures.}

Address correspondence and reprint requests to Dr. Dong Kuck Lee, Department of Neurology, School of Medicine, Catholic University of Daegu, 3056-6 Daemyung 4 Dong, Nam-Gu, Daegu, 705-718, Korea;dklee@cu.ac.kr

1. Jamjoon BA, Cummins BH. The diagnosis of ruptured intracranial dermoid cysts. Br J Neurosurg 1989;3:609612.

2. Mikhael MA. Transient spasm of carotid siphon complicating ruptured dermoid cyst. Radiology 1982;114:824. 


\section{Neurology}

\section{Intracranial dermoid cyst rupture with midbrain and thalamic infarction \\ Min Goo Kang, Kyung Jib Kim, Jung Im Seok, et al.}

Neurology 2009;72;769

DOI 10.1212/01.wnl.0000343062.44658.fd

This information is current as of February 23, 2009

\section{Updated Information \& Services}

References

Subspecialty Collections

Permissions \& Licensing

Reprints including high resolution figures, can be found at: http://n.neurology.org/content/72/8/769.full

This article cites 2 articles, 0 of which you can access for free at: http://n.neurology.org/content/72/8/769.full\#ref-list-1

This article, along with others on similar topics, appears in the following collection(s):

Diplopia (double vision)

http://n.neurology.org/cgi/collection/diplopia_double_vision

DWI

http://n.neurology.org/cgi/collection/dwi

Infarction

http://n.neurology.org/cgi/collection/infarction

MRI

http://n.neurology.org/cgi/collection/mri

Surgical therapy-tumor

http://n.neurology.org/cgi/collection/surgical_therapytumor

Information about reproducing this article in parts (figures,tables) or in its entirety can be found online at:

http://www.neurology.org/about/about_the_journal\#permissions

Information about ordering reprints can be found online:

http://n.neurology.org/subscribers/advertise

Neurology ${ }^{\circledR}$ is the official journal of the American Academy of Neurology. Published continuously since 1951, it is now a weekly with 48 issues per year. Copyright . All rights reserved. Print ISSN: 0028-3878. Online ISSN: 1526-632X.

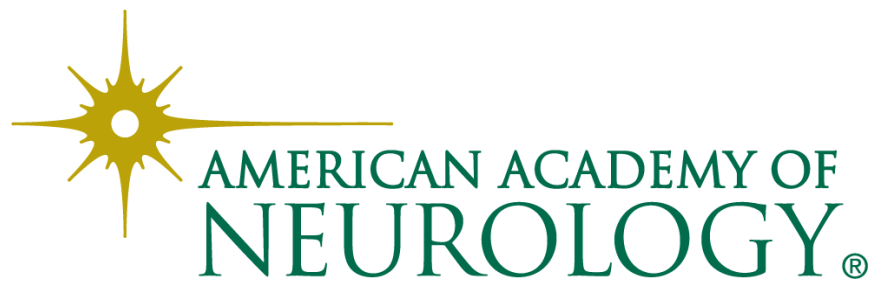

